\title{
Defining Māori language revitalisation: A project in folk linguistics ${ }^{1}$
}

\author{
Nathan John Albury
}

University of Oslo, Norway

The postmodern and critical movements in language policy, with their redefinition of governmentality and attention to power structures call for localised perspectives on language arrangements. In this way apolity, in its social and cultural context, can be understood as much as the policies it operates. In the case of Indigenous languages undergoing revitalisation, this allows us to define language revitalisation, and the vitality it should deliver, not through western scholarship but for localpurposes with local ideas by examining local knowledge and preferences. To do this, a folk linguistic approach was applied to language policy research. A quantitative and qualitative survey investigated how around 1,300 Indigenous and non-Indigenous youth in New Zealand défine Māori language revitalisation from their own perspective and how they perceive the revitalisation processes and outcomes proposed in scholarship and local discourses. The paper shows that claimed linguistie knowledge not only exists parallel to language attitudes, but informs local policy ideas. The findings indicate that these youth define language revitalisation and vitality in terms contextualised by locaK ontology, knowledge, ideologies and values, therefore challenging the ocal applicability of universal theories.

Ko tā te hunga e whai ana i ngā kaupapa o te Aohōutanga me te Āta Pakirehua, he karanga kia whai wāhi ngā whakaaro o ngā marahea ki ngā whakaritenga reo. Koinei te hua o tā rātou tohu i te pēwheatanga o te kāwanatanga mā te aronui atu ki ngā pūnaha whakawhāiti mana. Mā konei e paărama ai ngā kaupapahere e whakahaeretia ana e te rōpū pakipaki, kia rite ai ki tōna horopaki ā-ahurea, me tōna horopaki $\bar{a}$ - hapori hoki Na reira e taea ai tēnei mea te whakarauora reo te whakaahua mō nga reo taketake e whakarauorahia ana, me te taumata o te oranga e wawatahia ana, kaua ki tā te hiahia o te hunga mātauranga tauiwi, engari, ki tā te hiahia o ngā marahea, mā te àta rangahau i tō ngā marahea mōhiotanga me $\bar{o}$ rātou pīrangi. Kia puta mai ai tēnei mōhiotanga, ka whāia tētahi tikanga ngaio wetereo $\bar{a}$-marahea hei tātari kaupapahere rangahau reo. I tirohia e têtahi uiuitanga à-ine kounga, ā-ine tātai hoki, ngā whakaaro o te 1300 taitamariki taketake, taitamariki tauiwi hoki, nō Aotearoa, me tō rātou māramatanga o te mahi whakarauora reo. I tirohia hoki te āhua o tā rātou kite i ngā tukanga whakarauora reo me ngā hua e matapaetia ana e ngā kōrero a ngā tāngata mātauranga me ngā marahea hoki. E whakaatu ana tēnei pepa ka tū 
ngātahi te mōhiotanga $\bar{a}$-reo ki te taha o ngā waiaro reo, ā, ka riro taua mōhiotanga hei tūāpapa o ngā ariā mō ngā kaupapahere marahea.E tohu ana ngā kitenga e whakaahuatia ana te ariā o te kaupapa whakarauora reo me te oranga reo e ngā taitamariki ki tā ngā ariā e whakahoropakitia ana e te mātauranga tīari me te mōhiotanga me ngā ariā me ngā waiaro ki tā te marahea titiro, à, mā reira e werohia ai te hāngaitanga o ngā ariā e mau whānui ana ki te taiao ā-rohe. [Māori]

KEYWORDS: Folk linguistics, language revitalisation, language policy, language vitality, Māori

\section{INTRODUCTION}

Sociolinguistics is not short of discussion on what factors might indicate growing language vitality for endangered Indigenous languages. Fishman's (1991, 1993, 2000) reversing language shift (RLS) theory has in no small part guided revitalisation scholars, practitioners, and enthusiasts around the world, including in New Zealand. It proposed the importanke of achieving particular language goals, including the reinstatement of intergenerational transmission of the minority language in homes, increassing literacy, and expanding domains of language use. It also positioned ethnonationalist identity as the key rationale for language revitalisation (Fishman 2001: 17). The United Nations' (UNESCO 2003) guidelines have since followed Fishman's lead. Conklin and Lourie (1983) had contributed too, with the view that stable residence of speakers, nationalist aspirations social and economic mobility, literacy, and whether or not the minority relies on an agreed orthography, all contribute to determining the fate of a minority language. Despite benevolent theorising, however, the situation for Ondigenous languages oftentimes remains grave.

However, a postmodern and localist turn in the scholarship has decentralised perspectives on language policy (Canagarajah 2005; Pennycook 2006). Language poliey actors are now seen as many across society, including those who create poljey for their own local situations, such as at home or in community groups, and those who interpret top-down directives, such as schools. Accordingy, the success of top-down policies and the creation of micro policies are gutided by societal attitudes and ideologies (Spolsky 2004), as well as the linguistic knowledge of these non-linguists, even if this contrasts with empirical knowledge from the academy (Albury 2016; Canagarajah 2005).

Giving credence to local perspectives in language policy means viewing theories such as Fishman's and the United Nations' with scepticism because although they assume universal validity, they are premised in western values. For example, the value they place on standardisation and literacy draws on modernist ideas of coherence and structure (Foucault 2003) rather than Indigenous ontologies that define language vitality differently, or indeed generally care less about the relative 'health' of languages. Coulmas (1998: 71) 
even suggests that fervour about language loss harks back to a "nineteenthcentury romantic idea that pegs human dignity as well as individual and collective identity to individual languages' rather than non-European concerns about language. Ideas like these, plus the shortage of revitalisation success stories, leads to assertions such as Romaine's (2006: 442) that it is not entirely clear what conditions best support the survival and maintenance of linguistic diversity' and to Hinton's (2015) call to problematise who gets to determine what revitalisation means, and whose perspective counts in defining successful revitalisation. This creates a call to ascertain and understand the language policy ideas and preferences of communities themselves.

This paper advances such an inquiry in the case of the Māori language(also known as te reo Māori), as a revitalisation project in New Zealand (henceforth referred to as Aotearoa, its Māori name). It presents findings from aproject that applied the folk linguistics of language policy (Albury 2014a). Which brings the theoretical interests of folk linguistics to language policy research. This was applied in respect of a cohort of youth undergoing tectiary education to investigate how they define language revitalisation, its rationale and its goals, and how they feel about policy processes. The focus or youth follows the work of McCarty et al. (2009) that positioned Indigenous youth as policy makers because young adults often act 'as tiny social barometers' (Harrison 2007: 8). The linguistic biases and ambitions of youth are therefore pertinent as it is they who will lead guardianship of the langutage.

\section{THE CONTEXT OF AOTEAROA/NEW ZEALAND}

Te reo Māori is the Indigenøus language of Aotearoa and has been subject to community and government policies of revitalisation after its near total extermination by Britis bimperialists. The narrative of language loss and a subsequent interest in its revival is already well traversed (see for example Bauer 2008; Chrisp 2005; Harlow 2007; May and Hill 2005), so only pertinent themes are presented here. As the Waitangi Tribunal (2011) explains, Mâori language policy can be seen as comprising three main periods: colonial tolerance; language shift; and language revitalisation.

\subsection{Golonial tolerance (late 18th century to mid-19th century)}

The British began settling in Aotearoa en masse from the late 18th century. In this period, Māori remained the predominant language in Aotearoa, and it was especially common for British missionaries to become English/te reo Māori bilinguals rather than to impose language shift to English among Māori in the interests of Christianisation. It was also at this time that literacy was brought to te reo Māori (Harlow 2007). In 1840, the British Crown and Māori chiefs signed the Treaty of Waitangi to afford British sovereignty over Aotearoa while ensuring Māori would retain guardianship over Māori physical and cultural taonga ('treasures'). 


\subsection{Language shift (mid-19th century to 1970s)}

After a period of the British accepting the Māori language, British nationalism, coupled with notions of Social Darwinism (Benton 1996), inspired policies to anglicise the Māori in the interests of uniformity, modern nationhood and control. Measures included the 1880 Native Schools Code to eradicate the language as soon as possible and to enforce physical punishment for children who persisted in speaking te reo Māori on school grounds. As Māori began to urbanise, the government instituted its pepper-potting policy to settle Māori amongst Pākehā (European New Zealanders) in order to inhibit Māori language transmission in the community. As English became associated with modernisation and industry, it acquired prestige among many Māori who saw an instrumental value in language shift. By 1979, fewer than 100 children nationwide had high Māori-language proficiency (Waitangi Tribunal 2011).

\subsection{Language revitalisation (1970s to today)}

In the second half of the 20th century, Indigenous policy in Aotearoa, like in much of the colonised world, gradually took a 180 degree turn. A Māori cultural renaissance was born, coupled with demands for rights as tangata whenua ('people of the land') and to voice Māoritanga ('Māori tradition') (Kolig 2000). The government responded with institutional arrangements, including establishing the Waitangi Tribunal in 1975 to hear Māori grievances against the Crown. In 1989, the government granted an official infrastructure to the kohanga reo (Māori-immersion kindergartens) that Māori communities had established informally. Subsequent to a 1986 Waitangi Tribunal finding that the government had failed its constitutional duty to protect the language, legislation in 1987 codified te reo Māori as an official language of the state and established the Māori Aanguage Commission to oversee language revitalisation. The government pursued a biculturalist agenda whereby policy constructed the language as a concern for all contemporary New Zealanders. Non-Mâori were invited to become new speakers. The first Māori Language Strategy was released in 1997 and emphasised the language's contribution to a shared New Zealand identity (Albury 2014b).

After initial gains from the kohanga reo of the 1980s, the language base contracted again (Bauer 2008). Aotearoa has increasingly flirted with a neotraditionalist accent to its revitalisation policy, taking a lead from Fishman (1991). He sees language revitalisation as a matter of ethnonationalism for and by the minority, and considers intergenerational language transmission in the home as the critical step in achieving language vitality. Accordingly, the 2003 Māori Language Strategy emphasised Māori language transmission in the home, and policies have positioned Māori ethnic identity as linguistically informed, in turn constructing the language primarily as a matter for and by Māori (Te Taura Whiri 2015). This has been further fuelled by a 2010 Waitangi Tribunal (2011) finding that 'the Crown's protection of [the 
language] clearly needs to accord with Māori preferences - and, indeed, be determined in large measure by Māori ideas'. Aotearoa has responded, and in 2014 introduced a Bill to grant Māori tribal representatives oversight of language policy by way of Te Mātāwai, a new independent entity (Office of the Minister of Maori Affairs 2014). It is now estimated that only around 26 percent of Māori and one percent of non-Māori have any proficiency in the language (Te Puni Kōkiri 2006).

Recalling Hinton's (2015) argument that the meaning of language revitalisation should be perspective-dependent, the question must be posed of how New Zealanders, outside political corridors but with voting pdwer, understand Māori language revitalisation. Literature to date has reveated that New Zealanders are generally supportive of language revitalisation in the interests of culture and heritage, but that this tends not to manslate into language acquisition (Te Puni Kōkiri 2010). Chrisp (2005) explains that incipient bilinguals are often reluctant to use the language bécause of purist ideologies amongst elders that create feelings of ethnolingustic shame. de Bres (2015) found through a series of interviews with Nank Zealand government officials that a hierarchy of language values exists, again confirming the ideological dominance of English. While such Titerature addresses language attitudes, it does not discover how New Zeallanders themselves perceive and define language revitalisation from an epistemic perspective, such as what it comprises, how it happens and indeed why in a way that the folk linguistics of language policy might help reveal.

\section{A FOLK LINGUISTIC APPRQACH TO LANGUAGE POLICY}

Building on the established Madition of folk dialectology in applied linguistics (Preston 1993), this paper brings the theoretical premises of folk linguistics to language policy. In dolng so, it retains the tenets of folk linguistic theory that the folk have language awareness, such that they may claim knowledge on some linguistic topics and not others, and that this knowledge may be detailed, superficial, and empirically inaccurate (Preston 1996). Extending folk linguistics in this way contributes to the critical and poststructuralist turns in language policy research that decentralise knowledge authority, question unitersal truths, and seek out alternate epistemological biases that exist within language communities themselves. This makes the folk linguistics of language policy a direct reply to Pennycook's (2006: 62) argument that universalist 'tools and concepts that have been used to understand the world' should be questioned because governmentality in language is realised across society; not only by traditional authorities.

The paper especially draws on Albury's (2014a) folk linguistics of language policy research paradigm. This has a tripartite focus, firstly on what people who are not linguists claim to know in (socio)linguistics relevant to language policy, and secondly on how they feel about languages and policy topics 
(relying on the well-stablished field of language attitude research dating back to Lambert et al. [1960]). Here I rely on Ernest (1989), whereby knowledge is reasoned-based cognition that amounts to the logics and facts the folk claim in an area of linguistics. I treat these as facts even if these are empirically questionable, because claimed knowledge can form local truths and guide cognitive processes. Beliefs, on the other hand, are dispositional, evaluative and subjective. This may include attitude. Both knowledge and beliefs may be identifiable through stance-taking, albeit stances may be subject to change. The third focus is on how people perform language policy as policy makers, arbiters, implementers, and discussants (Albury 2014a).

The folk linguistics of language policy posits that discourses and decisions in language policy may be informed, to some degree, by what non-linguists claim to know as facts in linguistics, and not just by affect. I argue this in more detail (Albury 2016), where I showcase instances of individuals chiming and detailing (socio)linguistic knowledge relevant to language policy processes and then premising their policy ideas on this knowledge Begardless of the empirical accuracy of this knowledge, that paper illustrates how claimed knowledge can play an equal or greater role in the formation of language policy discourses. This is reminiscent of the preytous work of De Houwer (1999) and Mertz (1989) who found that parents tend to claim knowledge about the nature of bilingualism and second kanguage acquisition, and use this knowledge in deciding whether, and hav to raise children bilingually.

As such, bringing a folk linguistic perspective to language policy research is also a response to Canagarajah's (2005) call to localise knowledge in language policy. He argues that languagepolicy research that purports to understand local language issues, problems, and ambitions in local terms is best equipped by researching and giving qu hority to local knowledge. Canagarajah (2005: 20) advocates the importance of maintaining an ongoing conversation with local knowledge - if not to respect the aspirations and wholeness of marginalised communities, then at least for our common academic pursuit of broadening knowledge construction practices.

In as far as the postmodern and localist turns re-imagine governmentality and knowledge authority in language policy, then the impetus to investigate and understand folk linguistic knowledge has theoretical implications for language policy scholarship. As I argue (Albury 2016), language policy theories that seek to canvass the key influences in language policy design can and should be augmented to make space for folk linguistic knowledge as a potential influence. Whereas matters of ideology, disposition, and attitude tend to have found a home in language policy theory, the same cannot be said of claimed knowledge, and this currently misaligns with the postmodern and localist interests of language policy scholarship. In the case of endangered languages such as te reo Māori, a folk linguistics approach to language policy may help to identify hindrances to revitalisation as they exist in the sum total 
of knowledge and dispositions held by the many folk who engage in language revitalisation.

\section{METHODOLOGY}

An online survey invited the folk linguistic knowledge and beliefs of New Zealanders aged between 18 and 24 years attending the University of Otago in Dunedin in the South Island and living permanently in Aotearoa, and who selfidentify as Māori or Pākehā. Because identities in Aotearoa are much more blended than an ethnic dichotomy might propose, a third cohort was established for those who identify as both, referred to as Māori/Pākehā. As Paveau (2011: 41) reminds us, determining who the folk in fact are is one of the thorniest issues in folk linguistics'. In this project, folk linguists were defined as those who have never undertaken formal training in lipguistics. The research was endorsed by the Research Consultation Committee of Ngāi Tahu (the Māori tribe of the Dunedin area and much of the Soath Island) for its potential to generate valuable knowledge for Māori, and by the University of Otago's School of Māori Studies and Student Servikes.

With its reputation in health science, dentistry, physiotherapy, psychology, and the natural sciences, as well as its qualifications in the humanities and education, the University of Otago draws students from across Aotearoa. This includes Māori from Ngāi Tahu and fram beyond, as well as non-Māori. While Dunedin itself is not overrepresented tnits number of Māori language speakers, this did not influence the research design because the project investigated folk linguistic knowledge, not language proficiency. The University of Otago's student population is 9.2 percent Māori (University of Otago 2014), and therefore below average whereby Māori comprise 22 percent of university enrolments nationally (Wensvoort 2014), but similar to Aotearoa's other mainstream universities including Victoria University of Wellington (2015) which has 10 percent Māori, but higher than the University of Auckland (2015) where Marori form seven percent of the student body.

Because loeal folk linguistic data may be valuable to state policy makers, it was important that the data be usable by government. That meant collecting quantitative and qualitative data from a robust sample because - recalling my own experience as a policy advisor in Wellington - small-scale qualitative research involving few participants is rarely of use to public officials in democratic societies where statistics and some generalisability hold currency. This led to the decision to conduct the research using an online survey to gain a wide reach. Naturally, conducting large-scale research with as many respondents as possible limits the depth of qualitative data that can be obtained such as through interviews. In this case, however, the online survey offered other advantages. A robust set of quantitative and qualitative data could be obtained in a way that is reminiscent of the statistical and mapping exercises in traditional folk linguistics research. Also, the spatial distance created by an 
online survey gave the participants anonymity and the opportunity to present opinions as frankly, controversially, and as uncensored as they wished on a sensitive political topic without the sociocultural norms of a conversation. This proved beneficial and was evidenced by participants using inflammatory language and questioning their own belief systems in a way that politeness, shyness, pride, or other social inhibitors might not have facilitated in an interview.

The survey was sent across the student email network in September 2014. A total of 1,297 participants comprised the database, including 1,090 Pākehā, 54 Māori, and 153 Māori/Pākehā. The cohort comprises Pākehā and Măori from various locations and disciplines. This includes students whose majors are more distant from language policy such as medical students, and Strdents whose subject matter is somewhat closer such as students of history, education, or of the Māori language itself. The ratio of Indigenøus to nonIndigenous students broadly reflects the composition of the student population, but the unequal sizes of the groups means the data should bot be relied upon for statistical comparisons. The project is therefore a case study of bringing a folk linguistic perspective to language policy and of the perspectives of young university students on language revitalisation. The results may be generalisable to youth at mainstream univêrsities in Aotearoa, given the Otago student body has national representation and various disciplines. However, it cannot, for example, be seen as representing the folk linguistic perspectives of North Island communities where the language enjoys greater relative vitality, of students at/Maori-medium universities, or of more conservative groups such as Māopri elders and older Pākehā.

The quantitative component of the survey solicited levels of agreement, using a five-point Likert (1932) scale, to a series of 26 statements. The statements were categorised into two main groups:

- the value, rationale, and actors of language revitalisation; and

- the nature and processes of language revitalisation. This was framed by Hornberger's (2006) language policy and planning (LPP) model that sees policy interventions as concerning the status, the corpus, or the acquisition of a language.

The statements reflected prominent themes that arise in language revitalisation scholarship as well as in local policy and discourse. The statements were drafted either as epistemic or evaluative stances (Jaffe 2009) to which the respondents were asked to rate their level of (dis)agreement. For example, under the language acquisition planning category, statements included 'language revitalisation is about more and more people learning to use te reo Māori' which solicited epistemic (dis)agreement with whether Māori language revitalisation includes language acquisition, and 'to revitalise te reo Māori through the school system, it should be a compulsory subject in all 
schools in New Zealand (like maths and English)', which solicited dispositional (dis)agreement. After each statement, the students were invited to provide free text to nuance their quantitative response. Together, the quantitative and qualitative data would allow for an investigation of ideologies of language revitalisation as they are realised in epistemic and dispositional terms measured quantitatively and qualitatively. The Appendix provides the structure of the survey.

Analysis of the quantitative data showed that in the vast majority of cases, Māori and Māori/Pākehā responded almost identically. As such, and given the Māori cohort is much smaller than the others, Māori and Māori/Pākehā have been merged when reporting quantitative data, but discussion of the qualitative data will continue to refer to all three groups. In the following sections, quantitative data will generally be presented first, follgned by more analytical discussion drawing on the qualitative data that nuances the quantitative findings.

\section{VALUE, RATIONALE, AND ACTORS OF REVITALISATION}

This section sets outs what the youth saw as the yalue, rationale and actors of language revitalisation. It especially shows that, even though not all were convinced that te reo Māori is endangered, they agreed that language revitalisation supports both Māori culture and an interethnic national identity. However, it also shows that the partiempants - and especially Pākehā - tended to hierarchise language values<whereby they see a cultural impetus to revitalise te reo Māori, but việ the economic impetus to focus on foreign languages as stronger.

In any case, all cohorts Agreed that revitalisation work is desirable; the majority was stronger anongst Māori and Māori/Pākehā, with almost all agreeing or strongly endorsing investment in revitalisation policy, compared to 66 percent of Päkeha. A majority in all cohorts agreed that revitalisation is a responsibility shared across society, but whether the government should carry a key role dftracted debate, with over three quarters of Māori and Māori/ Pākehā feeling the government is responsible, but only 57 percent of Pākehā.

Howerer, it must be noted that not all participants were convinced the language is endangered. Those who felt the language is not endangered appear to have defined what language vitality should mean for te reo Māori, and what the revitalisation process should produce, in their own terms. Some claimed the language enjoys vitality because it is visible in the linguistic landscape and is supported by an ideological or political infrastructure. Others felt the language is healthy because it has offered loanwords to English and because it is taught to a basic level in primary schools. Some Pākehā claimed knowledge, albeit erroneous, that the language is spoken widely in Māori homes and is a compulsory school subject. Some explained that it is a natural part of contemporary Aotearoa and safe by default, with views such as 'I think it is a 
part of New Zealand and won't disappear because the country itself won't disappear'. For a more detailed discussion on Pākehā folk linguistic perspectives on Māori language endangerment, see Albury (2015). Māori respondents often agreed with Pākehā, suggesting that an optimal level of language use and acquisition has already been achieved. They argued, for example, "we have full immersion learning centres that target all generations ... it is alive and kicking'. This contrasts with the opposing view that current rates of language use and acquisition are not sufficient. Concerns arose that while the language may not disappear, a tendency to tokenise the language for cultural indexicality jeopardises its communicative value and the proficiency of its users. Pākehā explained that 'kia ora ['hello'] an@other common sayings will always be around. The frequency and depth-of the language is at risk of nearly dying'. Māori responded similarly fremining 'we will always use basic Māori words ... however being fluent 10 Te Reo is disappearing'.

Whereas Māori and Māori/Pākehā often positioned langựge revitalisation in its postcolonial context with obligations on the state to rectify past injustices, Pākehā viewed the language as one of many socialissaes detached from the politics of reconciliation. Pākehā who disagreed with ongoing investment in revitalisation claimed that Aotearoa is facing more important policy issues, arguing that 'wasting government and sckools time and money on teaching Maori instead of dealing with important issues is poor delegation of resources'. As I have argued elsewhere (Albury 2015), narratives of language loss and colonisation may hold decreasing/prominence in the collective memories of Pākehā. Māori, however, often offered a counterview that the government is especially responsible, given the state was 'the main reason of the loss of te reo Māori'.

Respondents were asked to rate their agreement to various rationales for revitalisation. These had been drafted with Ruiz's tripartite (1984) notion that polices construct fanguages (1) as a right, (2) as a social, cognitive, cultural or economic resdurce, or (3) as an impediment. If respondents considered te reo Māori to be-in the third category of Ruiz's theory, an impediment, they were free to disagree with all the rationales and explain their position. The language as a resource notion drew on revitalisation rationales that arise in langurge policy literature and discourses in Aotearoa, such as the relationship between language and identity (Baker 2011), language rights (May 2005), the cognitive benefits of bilingualism, and the functions of a revitalised language (Fishman 1991; Romaine 2006). Figure 1 gives the quantitative results.

These data suggest that a hierarchy of language values exists whereby the cultural value of any language is important, but not as important as an economic value. That is to say, learning te reo Māori for cultural reasons is sound, but languages of perceived economic value should take precedence. For example, Pākehā presented views such as 'I think the reasons for revitalisation 


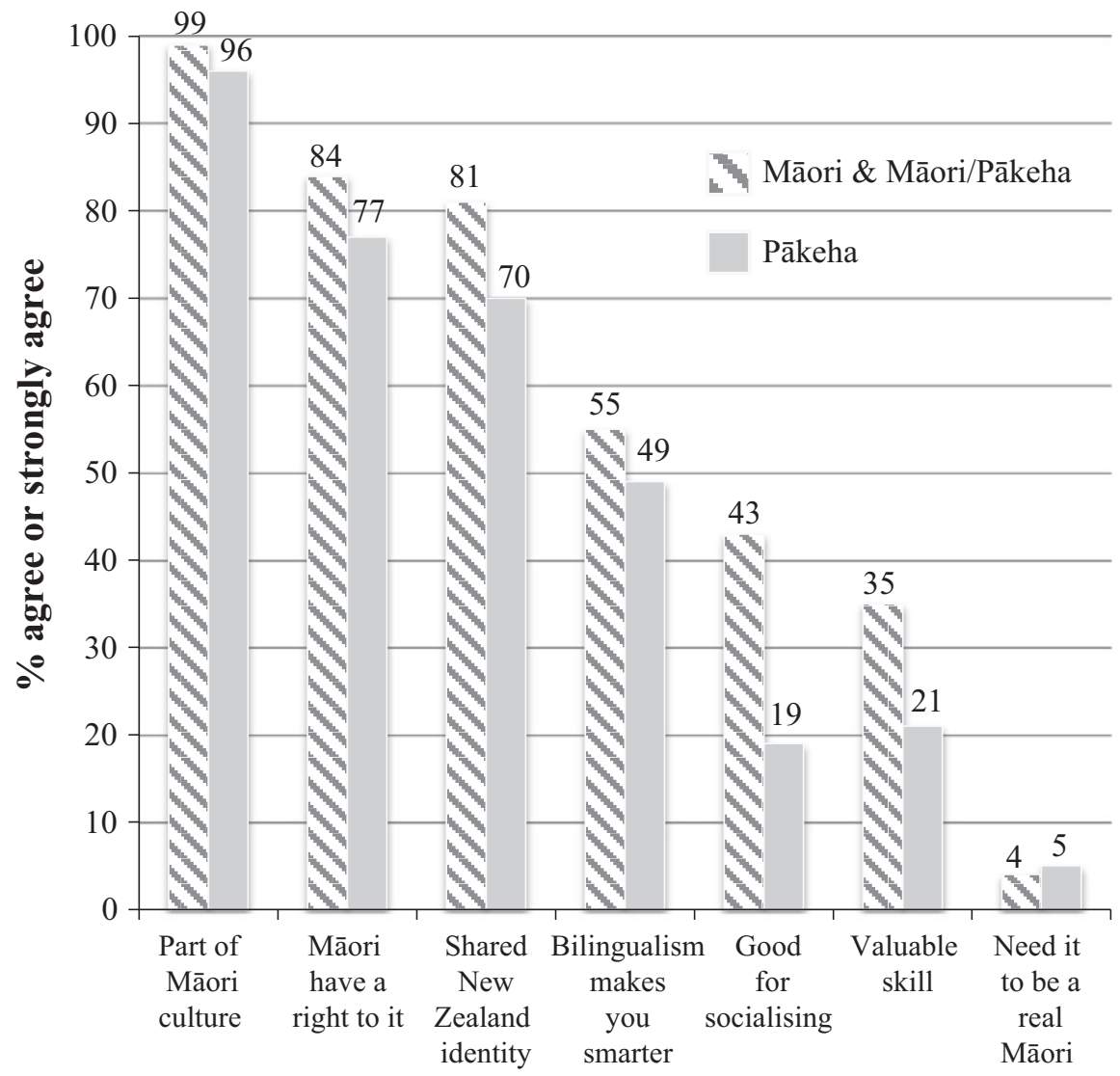

Language revitalisation rationale

Figure 1: Rationales for revitalising the Māori language

should be befause of the high worth of the Māori language and culture as a part of New Zealand and our history and identity'. However, this was often trumped by the language's perceived lack of economic value. This cast doubt op whether the cultural rationale is in itself sufficient grounds for revitalisation and whether te reo Māori should precede foreign languages in the school curriculum. For example, Pākehā participants explained that the language 'is a cultural novelty rather than a useful investment' and that 'it's a cultural thing, it won't help in the wider world', and a Māori/Pākehā participant explained that 'we would be better off learning a language that can be used internationally'.

On the one hand, these views may suggest that te reo Māori has not obtained what May (2000) and de Bres (2008) call tolerability amongst Pākehā. They argue that as a policy objective, a language undergoing revitalisation must 
become ideologically tolerated by the majority. However, in this case where Pākehā favoured economy over culture, their free text responses nonetheless positioned te reo Māori as a vital marker of interethnic contemporary New Zealandness. For example, Pākehā argued that it is very important to ... NZ identity as a whole' and that 'regardless of ethnicity, I believe New Zealanders collectively have a right to it'. Māori respondents agreed, claiming 'te reo Maori is an aspect of not only Maori culture but also the culture and identity of Aotearoa', and 'it's essentially a part of every NZer :)'. This suggests that the language is more than tolerated by Pākehā, and even appropriated by them into their sense of national citizenship albeit they are sceptical of its econolmic value and their need to learn it. For Aotearoa then, I would suggess, the question is not how tolerable the language is to Pākehā. Instead, the question is how Pākehā appropriation of the language into the national identity is or is not realised through individual language acquisition and societal bilingualism, and secondly to what extent this national language-identity correlation translates into individual identities. The former is a mattey to be addressed from a folk linguistic perspective in this article.

In any case, the biculturalist leanings of the cohort ehallenge revitalisation theory and the neotraditionalist policy currently (in) place in Aotearoa. Firstly, the relevance of essentialism, whereby language exists in a lineal relationship with ethnic identity (May 2005), is especially questionable. Respondents across the cohorts almost unanimously rejected the notion that Māori identity relies on the language. A Māori respondent explained that 'you don't have to speak Māori to be a real Māori. It is abouł /whakapapa [Māori genealogy] instead' and a Māori/Pākehā respondent exp̧tained that 'Māori isn't defined by speaking Māori ... it's more about kow much you embrace the culture as yours'. Fishman (2000: 465), honever, argued that 'RLS cannot be based on acts of charity by outsiders' because it relies on an ethnolinguistic group's cultural identity. UNESCO (2003: 14) also considers language 'essential to ... community and identity'. Even local discourse claims that without te reo Māori, 'Māori idehtity would be fundamentally undermined, as would the very existence of MPori as a distinguishable people' (Waitangi Tribunal 2011: 442). These clains, may be useful for revitalisation activists, but were refuted by these youths. The ideas of the cohort sooner align with claims to the contrary, such as Baker's (2011: 398) that if language were indeed an essential precursor to ethnic identity, then ' $99 \%$ of Scottish people would not identify as being Scottish' and my own view (Albury 2014b) that Māori sooner draw on whakapapa for ethnic identification than on language.

\section{WHAT LANGUAGE REVITALISATION COMPRISES}

This section discusses how the participants defined language revitalisation, using the LPP orientations as its guide. It especially shows that the cohorts agreed that revitalisation is primarily a matter of status and acquisition 


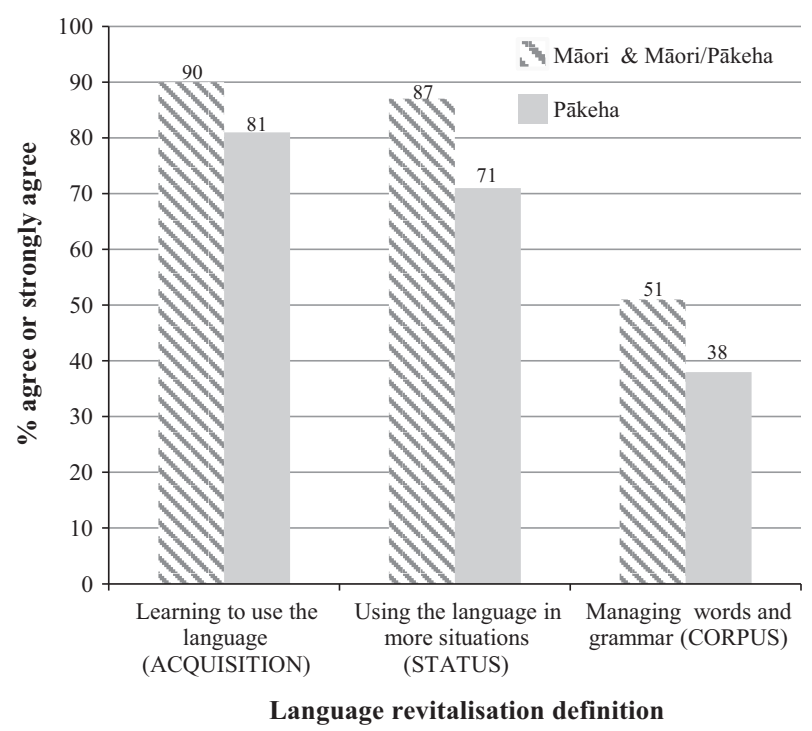

Figure 2: Folk knowledge of what language revitalisation means by language policy and planning (LPP) orientation and cohort

planning, but to a much lesser extent one of corpus planning. This is shown in Figure 2. Discussion now focusses on foll Minguistic perspectives as they relate to each LPP orientation.

\subsection{Status planning}

As illustrated in Figure 2, the respondents agreed that increasing use of te reo Māori in more domains ss key to revitalising and normalising it. This section also shows that while the participants strongly support linguistic diversity, they were concerned about the language rights of monolinguals and about striking a balancelbetween the cultural value of te reo Māori and the economic value of English when considering what domains te reo Māori should occupy.

This is not to say that the respondents all endorsed status planning, but that their folk linguistic knowledge - distinct from their dispositions - understood status planning to be a revitalisation endeavour. As one Pākehā respondent explained, 'I don't agree with it being used in more situations but that is how it will be revitalised'. However, the participants strongly endorsed societal multilingualism, with only seven percent of Māori and Māori/Pākehā and 22 percent of Pākehā agreeing that it would be better if everyone in Aotearoa spoke the same language across domains. Nonetheless, a sizeable proportion chose neutral agreement to the idea of societal monolingualism (22\% Māori and Māori/Pākehā, and 25\% Pākehā).

Free text from Māori participants often challenged the Māori demands for a bicultural rather than multicultural Aotearoa that are commonly reported in 
Māori politics and discourse (see, for example, Higgins and Rewi 2014). Rather than upholding this rhetoric to the exclusion of new minorities such as the various Pasifika and Asian communities, Māori participants endorsed multiculturalism, claiming that 'New Zealand is a place where people come from all over the world and only speaking one language would be insulting to the rest'. Māori/Pākehā respondents also explained that 'language, nationality, culture, sub-cultures, ethnicity all provide new ways of looking at the same picture'. Interestingly, Pākehā were more likely to focus on preserving a bicultural national identity and the status of te reo Māori. They explained that 'NZ is a bicultural country' and 'we are a bilingual nation'.

Although many participants showed neutral agreement to sokietal bilingualism, this should not be interpreted as lack of interest becausefree text commentary often revealed sophisticated deliberations. Pākehā añ Māori/ Pākehā comments focused on three main themes. Firstly, respondents offered a principled argument - without overtly biasing any language that societal bilingualism would require widespread individual bilingtality. They raised a concern that societal bilingualism would disenfranchise Aotearoa's monolinguals and incipient bilinguals. They especially argued that this would encroach upon an individual's right to use and be spoken to in their own language, such as that 'we need to respect that people don't have the opportunity to learn another language ... that is not their own / they can't learn it as they just aren't good at it'. Secondly, respondents returned to the ideological dilemma of choosing between economy and cultume, in this case between the efficiency of societal monolingualism and the cyltural benefits of bi- or multilingualism. For example, they argued '[monolingualism] does help with emergency situations and commerce. But it's a bitboring!', and 'yes for simplicity, no because our world is already encouraged to be over homogenised (variety is good, its culture!)'. Underscoring these arguments, it seems, was the assumed normativity of individual monolingualism, especially amongst Pākehā. Reference was not made to encouraging high-level individual bilinguality amongst Pākehā.

Thirdly, and ds Figure 3 shows, the respondents sought to resolve the tension between the economic instrumentality of English and the cultural value of tè reo Māori by suggesting the languages be compartmentalised. This meant allowing te reo Māori to be used in both formal and informal domains, but onty where Māori culture is key, such as in official ceremonies and in Màri homes. Other shared spaces would be kept monolingual in English. Māori themselves argued that 'in many official situations it would be important to have one language, but in other circumstances this is not necessary, particularly in social situations, or in certain work situations'.

\subsection{Acquisition planning}

This section reveals that most participants not only see language acquisition as fundamental to language revitalisation, but also that it is an activity for 


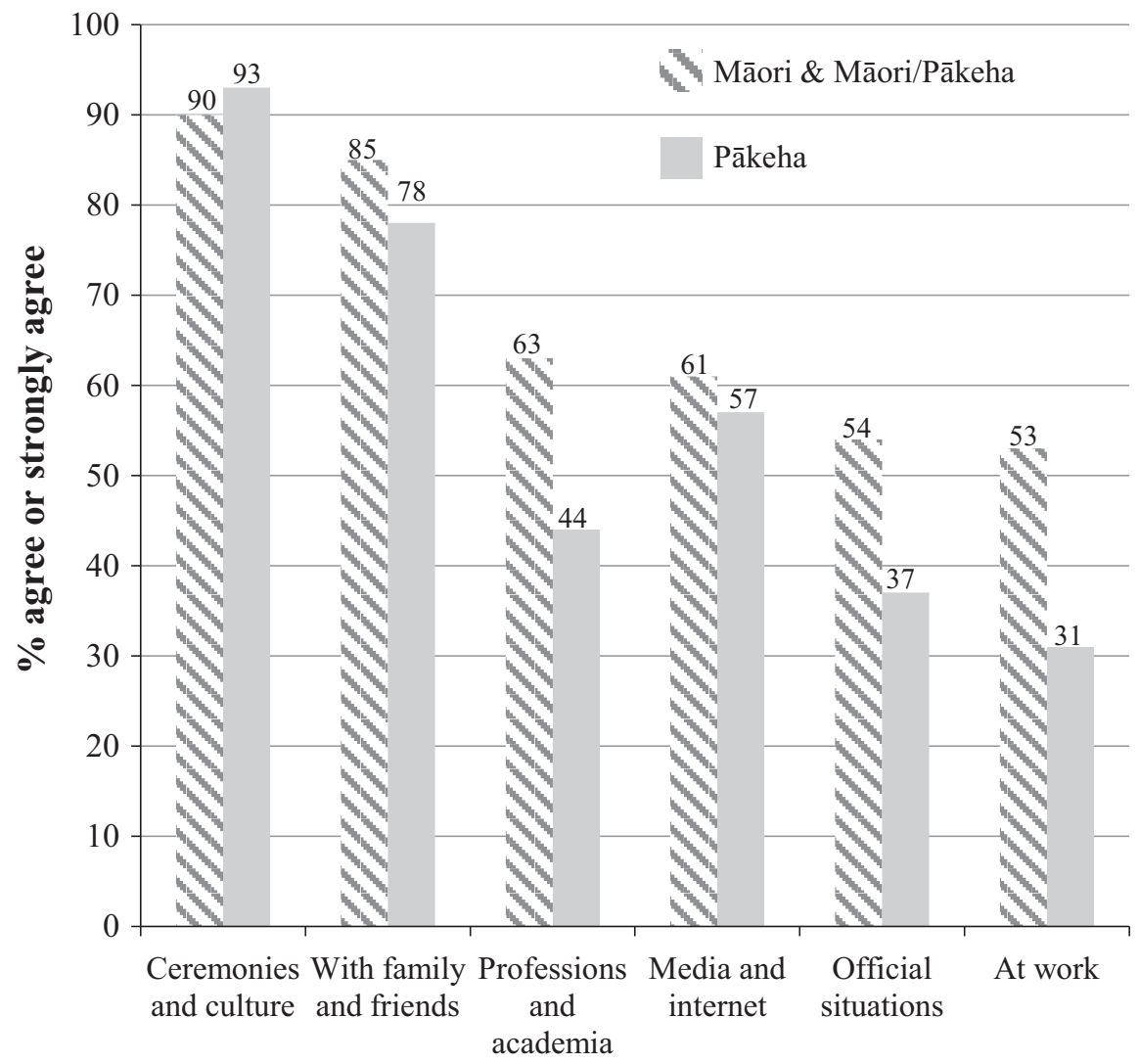

Māori language domain

Figure 3: Preferred domains for Māori language

classrooms specifically. By bringing a folk linguistic approach to discussions about language in education, the data also shows that attitudes against making te reo Măoria compulsory school subject were generally not premised in attitudes against the language, but in an ideology that hopes to see language revitalisation happen successfully, with well-resourced and effective language instruction.

As Figure 2 showed, all the cohorts saw language acquisition as a language revitalisation endeavour. Here, 75 percent of Māori/Pākehā, 69 percent of Pākehā and under half of Māori agreed that language revitalisation relies on parents speaking Māori to their children; however, as the following discussions will show, their free text commentaries tended to propose the opposite. Instead, almost all Māori and Māori/Pākehā, and 77 percent of Pākehā respondents claimed that language transmission is a responsibility of classrooms. However, fewer felt that te reo Māori should be made a compulsory school subject at some point in the education system, with only 63 percent of Māori and Māori/ 
Pākehā and just under half of Pākehā agreeing. Even fewer felt that all schools should be bilingual.

Despite the quantitative results, the statement that language vitality relies on intergenerational language transmission in the home attracted criticism from all the cohorts in their free text comments. They presented concerns about placing excessive responsibilities on parents, especially those who have acquired te reo Māori as a second language. Māori explained, 'it doesn't just fall to parents to teach children Te Reo Māori', and 'there are other options now'. Pākehā often agreed, with views such as that the language is sufficiently 'out there if they want to find it'. This lack of interest in home-balsed intergenerational language transmission may relate to the respondents -own conceptualisations of what language status should be achieved and what language vitality should mean going forward, as previously disenssed. For example, New Zealanders may not see a need for intergenerational language transmission if they are satisfied with the language simply becoming more prevalent in the linguistic landscape or in cultural ceremonies.

Instead, the cohorts all agreed that classrooms should be the primary site of language revitalisation. Māori argued that 'the eductation system is vital in ensuring that children learn when they are most malleable and open to learning a language'. Pākehā saw classroom-based revitalisation as ensuring that they, too, have exposure to the Māori world. In Aotearoa, neotraditionalist policy interventions that support home-based language transmission may therefore prove unpopular as these youth become parents. This scenario would be contrary to Fishman's (1991) befief that classrooms alone cannot be effective transmitters of language. The findings from Aotearoa are instead reminiscent of Romaine's (2006) observatiøns that vitality in the Basque, Welsh, and Irish languages is being achieved through classroom instruction, rather than through intergenerational langyagetransmission. Accordingly, some argued in favour of compulsory te reo Māori education, citing the language's legal status and education systems abroad that make space for Indigenous languages. For example, Pākeha respondents explained that 'it is one of our national languages and should be pespected and taught as such' and Māori agreed, explaining that 'Gaelic is compulsory in Ireland and nobody has died from it'.

In general, the findings corroborate previous attitudinal research which has shown strong opposition to te reo Māori becoming a compulsory subject in the curriculum (see, for example, Te Puni Kōkiri 2010). However, this project's focus on folk linguistic knowledge allowed attitudes in that debate to be better nuanced with underlying epistemic reasoning. Those who rejected the introduction of compulsory te reo Māori education often did so through sophisticated reasoning on policy constraints, and not because of negative affect against the language. This especially included concerns that making the language compulsory is not currently viable because of a lack of qualified teachers. For example, a Māori respondent explained 'our current mainstream 
schooling system is not capable of teaching Te Reo the way it should be taught', and a Pākehā participant commented:

Not enough teachers to be a viable option. Poorly taught language lessons would be a disaster (resentful kids \& parents) \& not useful learning going on. Should only consider making it compulsory if and when there are enough good teachers.

Others explained that compulsion may have the consequence of inadvertently creating hostility that would unfortunately impede the revitalisation process. For example, 'compulsorising Maori in the current social climate of New Zealand would be a mistake, as it would lead to resentment from people who do not support Maori culture in general' and

I don't think children would be able to learn the language well in schools if they were getting messages from home about compulsory Maori lessons being 'racist' and a waste of time, which is what I think would happen if,it was instated at the moment.

These views are informed by claimed knowledge about the teacher workforce and the ideological environment of language rewtatisation in Aotearoa, and not by negative affect. Instead, the attitudes against compulsory te reo Māori education are actually backgrounded by pøsitive support for the language and a desire to see language revitalisation occur as effectively as possible. Nonetheless, it must be noted that their broader endorsement for te reo Māori education was again affected by the culture versus economy dilemma. In particular, many argued that policy should aim for a lower level of compulsory study than for English. For example, Pākehā respondents explained that it should be compulsory up until high school age, and then become optional. Thapydy everyone at least has some knowledge and understanding of Maora language and culture'.

\subsection{Corpus planiping}

Around half̂f Māori and Māori/Pākehā, and significantly more Pākehā, did not see development of the te reo Māori corpus as contributing to language revitalisation. Those who included corpus planning activities in their definition of language revitalisation saw it as establishing the necessary linguistic foundations to achieve status and acquisition planning objectives, and developing te reo Māori into a legitimate and bounded language. This section now focuses on the reasons for not seeing corpus planning as language revitalisation. This especially includes the concerns about firstly developing communicative competencies before managing the corpus, about the impact on dialectal variation if a standard language is chosen, and about revitalising te reo Māori authentically as an oral language. It also shows that these local preferences are at odds with some core assumptions in language revitalisation and vitality theory. 
In the first instance, respondents prioritised oral language use above language form as the next important step in language revitalisation. Encouraging communication in the language is, they felt, in itself more pressing than creating and promulgating linguistic rules. Māori commented, for example, that 'it's more important to just get people talking rather than worrying about grammar'. Pākehā were doubtful too, commenting that 'defining a language doesn't bring it back to life'.

Secondly, the participants were especially sceptical of standardising te reo Māori. Some argued that dialectal variation in Aotearoa is not significant enough to warrant a standard for the purposes of improving intelligibility, with views such as 'as long as the different dialects are understood easily enough (like Australian vs NZ English), it's okay for them to be both corredt. Some Pākehā referred to power relations associated with choosing a standard, assuming that a standard language is necessarily chosen from existing varieties, claiming 'who gets to decide which dialect is better than the others?' and 'to restrict [one] in favour of the other would be completely moronic - they are both correct'. Others claimed epistemic knowledge that standard languages cannot coexist with dialects. They did not see standardisation as a complementary process, but as the homogenisatron or removal of dialects. For this reason, some were especially concerned about the impacts of corpus planning on culture and identity by exklaining that dialects index tribal affiliations. For example, Māori argued that each iwi [tribe] has their dialect and it is necessary to ensure that each $\mathrm{iwi}$ maintains each dialect as well as they can. That dialect is a part of who they are'. Others saw corpus planning as neocolonialism, such as the Pâkehā argument "why bother revitalising a language if you're just going to kill off subdialects to do it'. Māori agreed, and often asserted the normativity of dialectal variation, such as with the comment that 'many other counties eg Germany, France, England, America, have dialects and that's just the way it is!'.

Why the coexistence of a standard and dialectal variation was seen as impossible may be attributable to different factors. It may reside within an ethnolinguistip conscience that recalls the fate of te reo Māori under colonisation: with guilt on the part of Pākehā and with pain on the part of Māori. This national history may now have led these youths to equate language intervention with language shift. Alternatively, their reasoning may have been informed by their own lived experiences of English in Aotearoa. English is supported by a standard but is, by and large, monodialectal in Aotearoa with the exception of localised phonetic differences in the sparsely populated deep south (Burridge and Kortmann 2004: 568) and Māori English as a variety (Holmes 2005). In a global context, this variation is minimal. It simply may not have occurred to the respondents that a regional dialect and a standard can coexist, as they have not consciously experienced this. This was highlighted in a Pākehā comment that assumed that language standardisation in Indonesia has killed off linguistic variation: 'we need to keep diversity, look 
at Indonesia. Bahasa is the one embracing language for a diverse nation, I think we should foster the diversity'.

Lastly, many Māori and non-Māori were sceptical of corpus planning as it was not seen to comply with a traditional, pre-colonial Māori ontology of language. Some explained that the language is in direct relationship to Māori spirituality, leading Māori/Pākehā respondents to comment that language planning is not needed because te reo Māori is 'more about connecting with the past', and that 'it's a spiritual and 'felt' language. With more understanding comes more feeling, not better knowledge of grammar'. Others explained that authentic revitalisation does not require literacy in te reo Māori, because literacy was a colonial import taken up by the Māor poly in the 19th century. Māori explained that the language "needs to be beard not read' and Māori/Pākehā claimed that 'oral language is most important - this is how it was once passed down generations and how we should continue to pass it down generations'. This also challenges language revitalisation theory that sees literacy as a prerequisite to language vitality (Conklib/and Lourie 1983; Fishman 1991, 2000, 2001; UNESCO 2003). If language revitalisation is to proceed in local terms, then the importance of Indigenøus language literacy, as it has been assumed in theory, may hold little cout in Aotearoa. The findings instead support Hinton's (2003) theorising that literacy in the revitalisation process is often more relevant to Western European Indigenous languages such as Frisian, Irish or Basque than to Indigenous languages elsewhere.

\section{CONCLUSION}

Applying a folk linguistic perspective in language policy research proved able to reveal what a cohort of non-linguists feel about pertinent language revitalisation themes, as well as what they claim to know as linguistic facts and logics relevant to the revitalisation process. Knowledge and beliefs were often independent forces in the respondents' sociolinguistic reasoning. This was particularly ilustrated by participants using a traditional Māori ontology of language as an epistemic framework in order to justify their scepticism of standardissing te reo Māori and of positioning Māori language literacy as a policy goal. It was also apparent when respondents premised their attitudes agaiust making Māori a mandatory school subject not in negative affect, but in detailed knowledge about the current teacher workforce, the school curriculum, and the national ideological environment. These were strategic positions, backgrounded by a strong desire to optimise te reo Māori revitalisation by ensuring that a well-staffed teacher workforce is in place and the ideological environment is ready before the change to compulsory education is made. Without having explored folk linguistic knowledge, these attitudes may have been incorrectly attributed to an ideology against te reo Māori education.

The results from the survey are not representative of Aotearoa, as the sample only comprised tertiary-educated youth at a mainstream university in the 
South Island. To the extent that the respondents might represent Aotearoa's university population, then the data update and nuance previous literature on language ideology. In this regard, the data found that the cohort hold folk linguistic perspectives that may appear contradictory and are best understood by localising and contextualising knowledge and ambition in language policy (Canagarajah 2005). For example, Pākehā and Māori claimed that societal bilingualism is desirable, that te reo Māori is culturally valuable, that revitalisation is worthwhile, and that the language indexes a shared postcolonial national identity. These findings supported my discussion that the language is more than tolerated. However, the participants did not envishge Pākehā learning the language to a high level, were sometimes satisfied With a relatively low level of Māori language vitality, preferred confining the Ponguage to cultural and familial domains, and were sceptical of standardisation. Research contextualised by local knowledge and beliefs, however. Qeed not see these preferences as incompatible. Instead, the project revealed metalinguistic commentary from individuals that juxtaposed their deofacation that te reo Māori language indexes a shared national identity dgainst their parallel endorsement of an ideology that language learning is ar economic endeavour. They also recalled what they saw as an 'authentic' Māori linguistic culture which emphasises oratory tradition, meaning| they were less concerned with corpus development. For a mixture of these reasons, the participants agreed that Aotearoa's bilingual and biculturalist identity may be best realised by te reo Māori occupying formal domains that host Māori culture, as well as social and familial domains, but retaining English monolingualism in industry and the economy. In essence, the respondents explicitly and implicitly juggled competing ontologies and ideologies of language. Rather than discouraging revitalisation, they created Marori language vitality specific to the local context in a way that reconciles colture and economy.

The findings also show that folk linguistic data can offer much to language policy makers. Researching what is known leads to findings that can be critically positioned against the epistemic assumptions woven into government language polidjes. For example, whereas Aotearoa policy has taken a lead from Fishman's RLS theory, youth from this project do not see language revitalisation as an ethronationalist endeavour. By the same token, they are unlikely to accept that parents should carry responsibility for language transmission, having asserted in clear terms that this is primarily a responsibility for classrooms. These views are at odds with assumptions underpinning Aotearoa's language policy, and therefore need to be considered by Aotearoa's policy makers. However, this also means the findings contribute to the growing scepticism of universal language revitalisation theories that draw on Western European perspectives on language but assume universal relevance. If these theories continue to define language vitality in western ontological terms, then they will enjoy less applicability in the revitalisation of te reo Māori in Aotearoa. 


\section{NOTE}

1. I would like to express my gratitude to Allan Bell and Joseph Sung-Yul Park for encouraging this paper and overseeing it through to publication, and to the anonymous reviewers for their invaluable advice and enthusiasm. I would also like to warmly thank Tane Karamaina who translated the abstract to this article into te reo Māori. This work was partly supported by the Research Council of Norway through its Centres of Excellence funding scheme, Project Number 223265.

\section{REFERENCES}

Albury, Nathan John. 2014a. Introducing the folk linguistics of language policy. International Journal of Language Studies 8: 85-106.

Albury, Nathan John. 2014b. Your language or ours? Inclusion and exclusion of nonindigenous majorities in Māori and Sámi language revitalization policy Current Issues in Language Planning 16: 315-334.

Albury, Nathan John. 2015. Collective (white) memories of Mâori language loss (or not). Language Awareness. 24: 303-315.

Albury, Nathan John. 2016. The power of folk linguistic knowledge in language policy. Language Policy. doi:10.1007/s10993-016-940/44

Baker, Colin. 2011. Foundations of Bilingual Edruation and Bilingualism. Clevedon, U.K.: Multilingual Matters.

Bauer, Winifred. 2008. Is the health of te reo Maori improving? Te Reo 51: 33-73.

Benton, Richard. 1996. The Maori łangtuage in New Zealand. In Stephen A. Wurm, Peter Mühlhäusler and Darrall T. Tryon (eds.) Atlas of Languages of Intercultural Communication in the Pacific, Asia, and the Americas. Volume II: Texts. Berlin, Germany/New York: Mouton de Gruyter. 167-170.

Burridge, Kate and Bernd Kormann. 2004. Introduction: Varieties of English in the Pacific and Australasia. In Edgar W. Schneider and Bernd Kortmann (eds.) A Handbook of Varieties of English. Berlin, Germany: Mouton de Gruyter. 567-579.

Canagarajah, Surresh. 2005. Reconstructing local knowledge, reconfiguring language studies. In Suresh Canagarajah (ed.) Reclaiming the Local in Language Policy and Practice. Mawah, New Jersey; Lawrence Erlbaum. 3-24.

Chrisp, Steven. 2005. Māori intergenerational language transmission. International Journal of the Sociology of Language 2005(172): 149-181.

Conklin, Nancy and Margaret Lourie. 1983. A Host of Tongues. New York: The Free Press.

Coulmas, Florian. 1998. Language rights: Interests of state, language groups and the individual. Language Sciences 20: 63-72.

de Bres, Julia. 2008. Planning for tolerability in New Zealand, Wales and Catalonia. Current Issues in Language Planning 9: 464-482.

de Bres, Julia. 2015. The hierarchy of minority languages in New Zealand. Journal of Multilingual and Multicultural Development 36: 677-693.

De Houwer, Annick. 1999. Environmental factors in early bilingual development: The role of parental beliefs and attitudes. In Guus Extra and Ludo Verhoeven (eds.) Bilingualism and Migration. Berlin, Germany: Mouton de Gruyter. 75-95.

(C) 2016 John Wiley \& Sons Ltd 
Ernest, Paul. 1989. The knowledge, beliefs and attitudes of the mathematics teacher: A model. Journal of Education and Teaching 15: 13-34.

Fishman, Joshua. 1991. Reversing Language Shift. Clevedon, U.K.: Multilingual Matters.

Fishman, Joshua. 1993. Reversing language shift: Successes, failures, doubts and dilemmas. In Ernst Håkon Jahr (ed.) Language Conflict and Language Planning. Berlin, Germany: Mouton de Gruyter. 69-82.

Fishman, Joshua. 2000. Can Threatened Languages Be Saved? Clevedon, U.K.: Multilingual Matters.

Fishman, Joshua. 2001. Why is it so hard to save a threatened language? In Joshua Fishman (ed.) Can Threatened Languages be Saved? Reversing Language Shift, Revisited: A 21st Century Perspective (Multilingual Matters 116). Clevedon, U.K.: Multilingual Matters. 1-22.

Foucault, Michel. 2003. Abnormal. New York: Picador.

Harlow, Ray. 2007. Māori: A Linguistic Introduction. Cambridge, U.K.: Cambridge Dniversity Press.

Harrison, Gai. 2007. Language as a problem, a right or a resource? A study 0 how bilingual practitioners see language policy being enacted in social work. Journtal of Social Work 7: 71-92.

Higgins, Rawinia and Poia Rewi. 2014. ZePA - Right-shifting:-Reorientation towards normalisation. In Rawinia Higgins, Poia Rewi and Vincent Olsen-Reeder (eds.) The Value of the Maori Language: Te Hua o te Reo Maori. Wellington, Newzealand: Huia Publishers. 7-32.

Hinton, Leanne. 2003. Language revitalization. Annua Review of Applied Linguistics 23: $44-57$.

Hinton, Leanne. 2015. Leanne Hinton: What counts as a 'success' in language revitalization? Future Speakers: Indigenous Languages in the 21 st Century Series, University of British Columbia. Retrieved from https://www.youtube.com/watch?v=qNIUJxri3QY

Holmes, Janet. 2005. Using Māori Englishin New Zealand. International Journal of the Sociology of Language 2005(172): 91-115.

Hornberger, Nancy. 2006. Frameworks and models in language policy and planning. In Thomas Ricento (ed.) An Introduetion to Language Policy: Theory and Method. Malden, Massachusetts: Blackwell. 24.41.

Jaffe, Alexandra. 2009. Stance: Sociolinguistic Perspectives. New York: Oxford University Press. Kolig, Erich. 2000. Qf condoms, biculturalism, and political correctness: The Maori renaissance and cultural politics in New Zealand. Paideuma 46: 231-252.

Lambert, William E. Richard C. Hodgson, Robert C. Gardner and Samuel Fillenbaum. 1960. Evaluational reactions to spoken languages. The Journal of Abnormal and Social Psychology 60: $44-51$

Likert, Rensis. 1932. A technique for the measurement of attitudes. Archives of Psychology 140 (2) $1-55$.

May Stephen. 2000. Accommodating and resisting minority language policy: The case of Wales. International Journal of Bilingual Education and Bilingualism 3: 101-128.

May, Stephen. 2005. Language rights: Moving the debate forward. Journal of Sociolinguistics 9: 319-347.

May, Stephen and Richard Hill. 2005. Māori-medium education: Current issues and challenges. International Journal of Bilingual Education and Bilingualism 8: 377-403.

McCarty, Teresa, Mary Eunice Romero-Little, Larisa Warhol and Ofelia Zepeda. 2009. Indigenous youth as language policy makers. Journal of Language, Identity, and Education 8: 291-306.

Mertz, Elizabeth. 1989. Sociolinguistic creativity: Cape Breton Gaelic's linguistic tip. In Nancy C. Dorian (ed.) Investigating Adolescence. Cambridge, U.K.: Cambridge University Press. 103-116. 
Office of the Minister of Maori Affairs. 2014. A New Maori Language Strategy: Paper 2. Revised Ownership Arrangement for Maori Language Entities (Cabinet Paper). Retrieved from http:// www.tpk.govt.nz/docs/mls/tpk-mls-cab-248.pdf

Paveau, Marie-Anne. 2011. Do non-linguists practice linguistics?: An anti-eliminative approach to folk theories. AILA Review 24: 40-54.

Pennycook, Alistair. 2006. Postmodernism in language policy. In Thomas Ricento (ed.) An Introduction to Language Policy: Theory and Method. Malden, Massachusetts: Blackwell. 60-76.

Preston, Dennis. 1993. Folk dialectology. In Dennis R. Preston (ed.) American Dialect Research. Amsterdam, The Netherlands: John Benjamins. 333-377.

Preston, Dennis. 1996. Whaddayaknow?: The modes of folk linguistic awareness. Language Awareness 5: 40-74.

Romaine, Suzanne. 2006. Planning for the survival of linguistic diversity. Language Policy 5: $443-475$.

Ruiz, Richard. 1984. Orientations in language planning. NABE Journal 8: 1534 ?

Spolsky, Bernard. 2004. Language Policy. Cambridge, U.K.: Cambridge University Press.

Te Puni, Kōkiri. 2006. Te Oranga o te Reo Māori 2006 - The Health of the Mãori Language in 2006. Wellington, New Zealand: Te Puni Kōkiri.

Te Puni, Kōkiri. 2010. 2009 Survey of Attitudes, Values and Beliefs Fowurds the Māori Language. Wellington, New Zealand: Te Puni Kōkiri.

Te Taura, Whiri. 2015. Annual Report 2015. Wellington, New Zealand: New Zealand Government.

UNESCO Ad Hoc Expert Group on Endangered Lahguages. 2003. Language Vitality and Endangerment. Document submitted to the fnternational Expert Meeting on UNESCO Programme Safeguarding of Endangered Languages Paris, 10-12 March 2003. Paris, France: UNESCO.

University of Auckland. 2015. 2014 Annual Report. Retrieved from https:// cdn.auckland.ac.nz/assets/centrałabout/the-university/official-publications/documents/ AR\%202015\%20web\%20version\%20May\%2026\%202015.pdf

University of Otago. 2014. 2013 Annual Report. Last accessed 2 February 2015 at http:// www.otago.ac.nz/about/@ago669098.pdf

Victoria University of Wellington. 2015. Victoria University Annual Report 2014. Retrieved from http://www.victoria.ac,hz/about/publications/annual-reports2/2014-annual-report.pdf

Waitangi Tribunal. 2011. Wai 262 Waitangi Tribunal Report 2011. Wellington, New Zealand: Legislation Direct.

Wensvoort, Mieke. 2015. Maori tertiary education students in 2014. Education Counts. Last accessed 24May 2016 at www.educationcounts.govt.nz/publications/series/91676/maoritertiary-education-students-in-2014

Address for correspondence:

Nathan Albury

University of Oslo - Center for Multilingualism in Society across the Lifespan

Postboks 1102, Oslo

Norway 0317

n.j.albury@iln.uio.no 


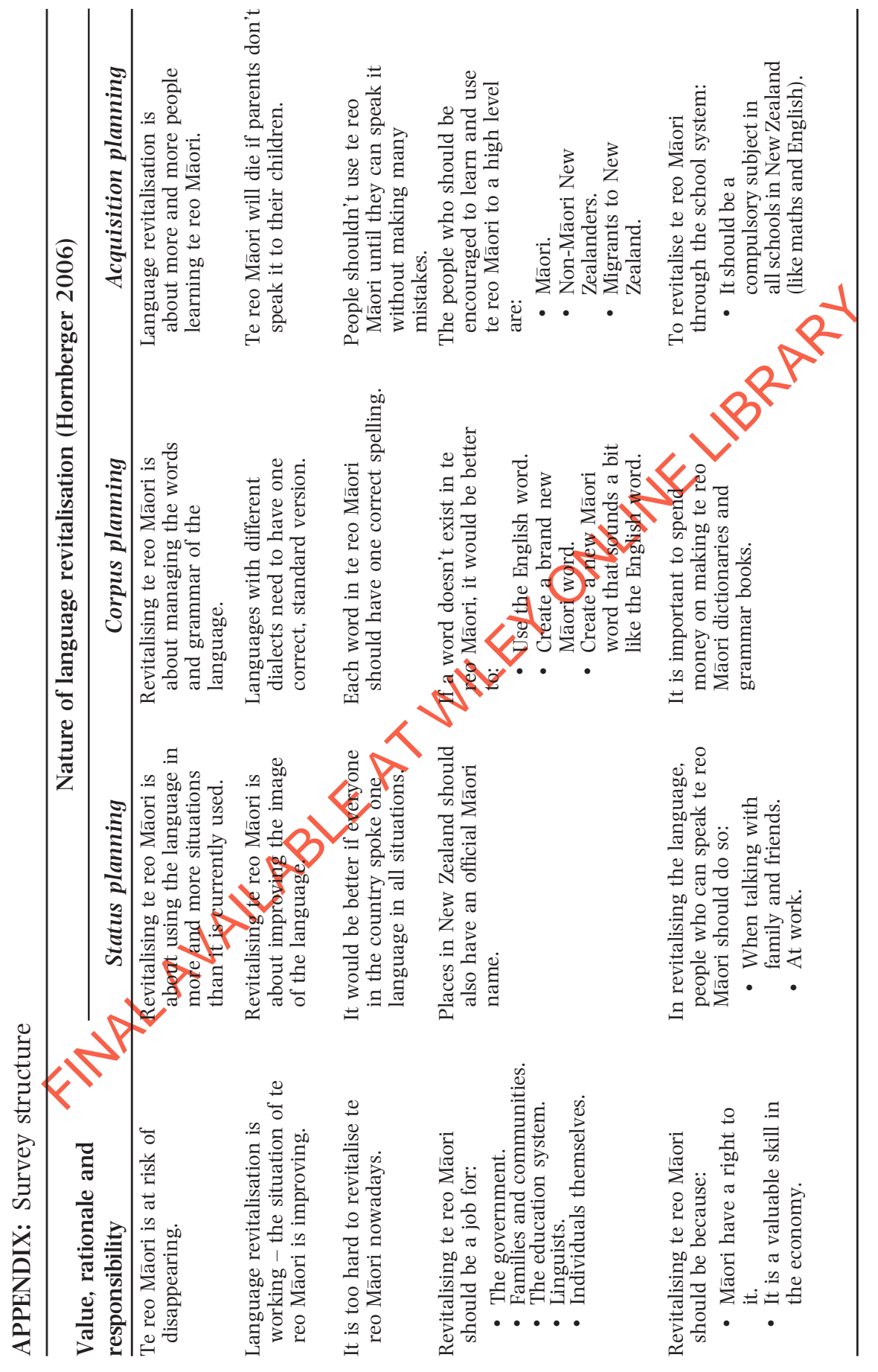




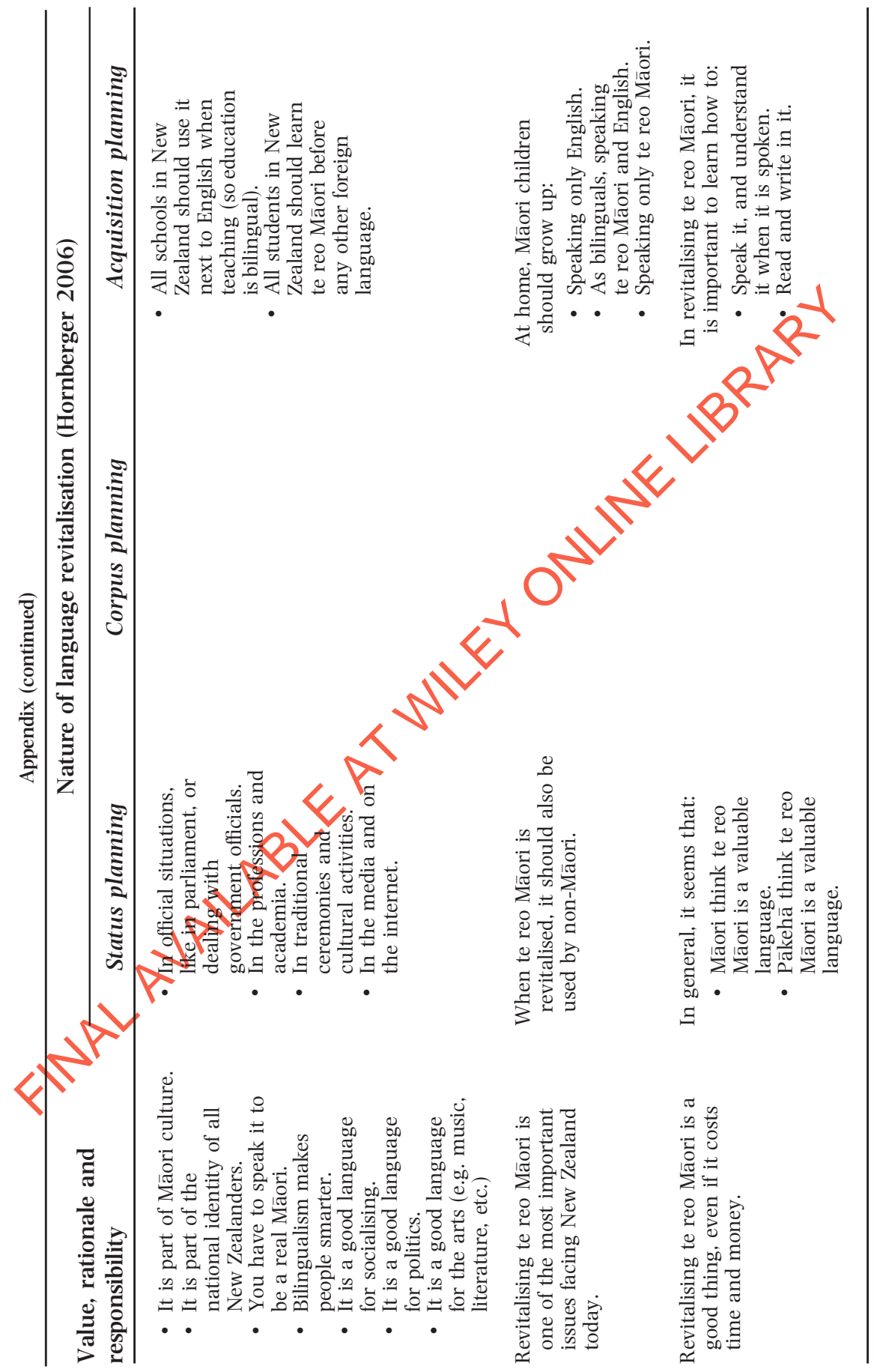

